\title{
Electrophysiological characteristics of enteric neurons isolated from the Immortomouse
}

\author{
Edward G. Hawkins ${ }^{1}$, William L. Dewey ${ }^{1}$, Mallappa Anitha ${ }^{3}$, Shanthi Srinivasan ${ }^{3}$, John R. \\ Grider $^{2}$, and Hamid I. Akbarali ${ }^{1},{ }^{*}$ \\ ${ }^{1}$ Virginia Commonwealth University, Medical College of Virginia Campus, Department of \\ Pharmacology and Toxicology, Richmond, VA, USA \\ ${ }^{2}$ Virginia Commonwealth University, Department of Physiology and Biophysics, Richmond, VA, \\ USA \\ ${ }^{3}$ Emory University, Division of Digestive Diseases, Atlanta, GA, USA
}

\begin{abstract}
Background-Recently two enteric neuronal cell lines, one fetal (IM-FEN) and the other postnatal (IM-PEN), have been developed from the $\mathrm{H}-2 \mathrm{~K}^{\mathrm{b}}$-tsA58 transgenic mouse (immortomouse). However, their electrophysiological properties are not known. The goal of this study was to determine the electrical excitability and ionic conductance of the immortalized postnatal enteric neuronal (IM-PEN) cell line.
\end{abstract}

Methods-Whole cell patch clamp studies, immunohistochemistry and RT-PCR were performed on differentiated IM-PEN cells following propagation at $33^{\circ} \mathrm{C}$ and differentiation at $37^{\circ} \mathrm{C}$.

Results-Differentiated IM-PEN cells stained positively for the neuron specific markers $\beta$ IIItubulin and PGP9.5. The mRNA for several ion channels expressed in enteric neurons were detected by RT-PCR. In current clamp, the resting membrane potential was $-24.6 \pm 2.1 \mathrm{mV}(\mathrm{n}=6)$ for IM-FEN and $-29.8 \pm 0.9 \mathrm{mV}(\mathrm{n}=30)$ for IM-PEN. Current injections from $\mathrm{Vh}-80 \mathrm{mV}$, resulted in passive responses but not action potentials. Depolarizing pulses in the whole cell voltage clamp configuration from $\mathrm{Vh}-80 \mathrm{mV}$ elicited small nifedipine-sensitive inward currents. Additionally, outward currents with slow deactivating tail currents were blocked by niflumic acid and low chloride solution. A volume-regulated anion current was elicited by hypo-osmotic solution and inhibited by $10 \mu \mathrm{M}$ DCPIB. Growth with rabbit gastrointestinal smooth muscle did not yield significant differences in the active properties of the IM-PEN cell line. Transient expression of L-type $\mathrm{Ca}^{2+}$ channels produced large inward currents demonstrating a working mechanism for protein folding and transport.

Conclusion-The electrophysiological characteristics of IM-PEN cells suggest that chloride channels in IM-PEN cells play an important role in their resting state and membrane trafficking of some of the ion channels may preclude their electrical excitability.

\section{Keywords}

Enteric neurons; cell line; Immorto-mouse; ion channels; whole cell voltage clamp

*Corresponding author: Hamid I. Akbarali, Professor, Department of Pharmacology and Toxicology, 1112 E, Clay Street, McGuire Hall 317, Virginia Commonwealth University, Richmond, VA 23298, USA. Tel: (804) 828-9688; fax: (804) 828-1532; hiakbarali@vcu.edu.

Disclosure: There are no conflicts of interests. 


\section{Introduction}

Enteric neurons play an essential role in the generation and propagation of gastrointestinal motility. Many of the features of enteric neurons including chemical coding, morphology and action potential characteristics have been examined in several species, including humans [1-4]. This has allowed for extensive classification of myenteric neurons as motor neurons, interneurons and sensory neurons. Electrophysiological characterization has generally led to two distinct patterns i.e. AH neurons with a long after-hyperpolarization, grouped as intrinsic primary afferent neurons, and $\mathrm{S}$ neurons corresponding to motor neurons and interneurons [3,5,6]. Most studies have relied on microelectrode recordings that reveal characteristics of the action potential but do not provide information on the biophysical properties of the underlying ionic conductance $[7,8]$. This is largely the result of the difficulty in dissociating isolated enteric neurons from the significant muscle layers which is necessary to establish spatial voltage clamp. Although recent research has also utilized whole-cell voltage clamp recordings, that using murine enteric neurons is still in its infancy [9-11]. Therefore it is of potential interest that an enteric neuronal cell line was recently developed from the immortomouse [12]. The immortalized enteric neuron cell line derived from the $\mathrm{H}-2 \mathrm{~K}^{\mathrm{b}}$-tsA58 transgenic mouse stably expresses a conditional immortalizing gene under the control of an interferon- $\gamma$ inducible tsA58 thermolabile Tag gene [13]. Enteric neurons obtained from post-natal day 2 mice (IM-PEN) by immunoselection were grown in conditions promoting neuronal differentiation including low serum and glial derived neurotrophic factor (GDNF). IM-PEN showed the presence of several neuronal markers by reverse-transcription polymerase chain reaction (RT-PCR) including cRET, three 5HT receptors, and the serotonin transporter (SERT). Implantation of these neurons into the distal colon of aganglionic mice (Piebald and $\mathrm{nNOS}^{-/-}$mice) resulted in recovery of the colonic neurogenic activity indicative of the potential use of these enteric cells in transplantation studies [12]. The goal of this study was to characterize the ionic conductance of IM-PEN cells.

\section{Materials and Methods}

\section{Cell Culture}

Immortalized enteric neuron (IM-FEN and IM-PEN)-cell propagation and differentiation occurs in 2 steps: 1) Cells were cultured in DMEM/F12 media, N2 supplement, interferon- $\gamma$ (20U ml ${ }^{-1}$ of recombinant mouse interferon- $\gamma$ ), GDNF $\left(100 \mathrm{ng} \mathrm{ml}^{-1}\right)$, antibiotic and $10 \%$ fetal bovine serum at the permissive temperature of $33^{\circ} \mathrm{C}$ in $10 \% \mathrm{CO}_{2}$. The cells were passaged when the flask became confluent using trypsin-EDTA $0.25 \%$. 2) To differentiate these cells towards a neuronal lineage, the medium was changed to Neurobasal-A medium containing B-27 supplement, $1 \mathrm{mM}$ glutamine, $1 \%$ FBS, antibiotic and GDNF $\left(100 \mathrm{ng} \mathrm{ml}^{-1}\right)$ and incubated at $37^{\circ} \mathrm{C}$ with $5 \% \mathrm{CO}_{2}$ for 5-9 days. Fresh media was added every 3 days to maintain a healthy cell population.

Rabbit smooth muscle cells and media were obtained as previously described [14]. For transfection IM-PEN cells were differentiated for 48 hours, transfected for 48 hours (under differentiation conditions) with EGFP and transferred to grow for 4 days on a culture of rabbit smooth muscle cells equaling a total of 8-9 days under differentiation conditions. cDNA containing the a 1c-subunit of the human jejunal $\mathrm{Ca}^{2+}$ channel $\left(\mathrm{hCa}_{\mathrm{v}} 1.2 \mathrm{~b}\right)$ along with the $\beta 2$ subunit (kindly provided by Dr. Farrugia, Mayo Clinic, Rochester, MN) and EGFP were transfected using recommended protocols. GeneJammer from Agilent Technologies (Santa Clara, CA) was used for the transfections. 


\section{Immunocytochemistry}

The IM-PEN cells were fixed with $4 \%$ formaldehyde solution for 1 hour and washed 3 times with PBS for 5 minutes before permeabilization with $0.1 \%$ Triton X-100 in PBS for 2 hours. The cells were washed 3 times in PBS for 5 minutes before addition of $10 \%$ goat serum for 1 hour. Another wash step with PBS preceded the addition of primary antibody ( $\beta$ III tubulin, PGP9.5, Abcam Inc., Cambridge, MA) at a dilution of 1:1000 with an overnight incubation at $4^{\circ} \mathrm{C}$. The TRPV1 primary antibody was used at a dilution of 1:2000 (Santa Cruz Biotechnology, Inc., CA). One of the following secondary antibodies Alexa Flour 488 or Alexa Flour 568 at a concentration of 1:500 was incubated for 2 hours (Invitrogen, Carlsbad, CA). Primary antibody was omitted for controls. Visualization was made using an Olympus FV300 confocol microscope (Olympus America Inc., Center Valley, PA,).

\section{Electrophysiological recording}

Whole-cell currents were measured in IM-PEN cells by the patch clamp technique. External and internal patch pipette solutions were experiment dependent and are detailed in tables 1 and 2. The $\mathrm{pH}$ of the external solutions was adjusted with $\mathrm{NaOH}$ and the osmolality was determined using freezing point depression on an Advanced Model 3300 Micro-Osmometer from Advanced Instruments, Inc. (Norwood, MA). Patch-clamp recordings in the whole-cell configuration were made at room temperature with an Axopatch 200B amplifier (Molecular Devices, Sunnyvale, CA). Patch pipettes with resistances of 3-5M $\Omega$ were pulled from borosilicate glass on a Flaming-Brown P97 electrode puller (Sutter Instruments, Novato, CA). Pulse generation and data acquisition were achieved using Clampex and Clampfit 10.2 software (Molecular Devices, Sunnyvale, CA). Data were acquired at $5 \mathrm{kHz}$ and filtered at $1-2 \mathrm{kHz}$. Series resistance did not exceed $5 \mathrm{M} \Omega$ and was not compensated.

\section{Reverse-Transcription PCR}

IM-FEN cells were cultured in the conditioned medium at $33^{\circ} \mathrm{C}$ or $39^{\circ} \mathrm{C}$ (for 3 days). Total RNA was isolated using the RNeasy Mini Kit. One microgram of total RNA was used to synthesize first-strand cDNA using the iScript cDNA Synthesis kit according to the recommended procedure. Reverse-transcription PCR was performed as described previously [15] with few modifications being $2.5 \mu \mathrm{l}$ of cDNA/25 $\mu \mathrm{l}$ reaction, and the reactions were subjected to 35 cycles of PCR amplification using the following oligonucleotide primers:

GAPDH (forward) $5^{\prime}$-TTGTGATGGGTGTGAACCACGA- ${ }^{\prime}$ and GAPDH (reverse) 5' -TCTTCTGGGTGGCAGTGATGG-3' .

Kcnn4 (forward) 5' - AGGCCACATAGCTCCACATGAACTC - $3^{\prime}$ and Kcnn4 (reverse) 5' - TGGATCCACTTGGGTCCTGGCA -3';

NaV_1.3 (forward) $5^{\prime}$ - GCTGTGCTCTCCCCATCAGTCTCT $-3^{\prime}$ and

NaV_1.3 (reverse) $5^{\prime}$ - TTGCGTCGCTCTCCAGGTCTGT - $3^{\prime}$;

TASK1 (forward) $5^{\prime}$ - CATCACCGTCATCACCACCATCGGCTA $-3^{\prime}$ and

TASK1 (reverse) 5' - TGACTAGTGTGAGCGGGATGCCCA - $3^{\prime}$;

Clca1 (forward) 5' - CCCCGAGGCAGAGTCTTTGTCCAT $-3^{\prime}$ and

Clca1 (reverse) 5' - GGCACGCCCTTGTGACACAGTT -3';

c-Ret (forward) $5^{\prime}$-ACGGCTGCATGAGAATGACTGGAT-3' and

c-Ret (reverse) 5' -CAGAAAGACCTGGAGGAAGATGGTGA-3'; 
Two thirds of each reaction was analyzed on $1.5 \%$ agarose gel stained with ethidium bromide, and the amplified products were visualized by ultraviolet transillumination.

Drugs

Unless otherwise noted the compounds used to make the various buffers were obtained from Sigma-Aldrich Corp., St. Louis, MO. The 4-[(2-Butyl-6,7-dichloro-2-cyclopentyl-2,3dihydro-1-ox o-1H-inden-5-yl)oxy]butanoic acid (DCPIB) was obtained from Tocris Bioscience, Ellsville, MO.

\section{Results}

\section{IM-PEN have a neuronal background}

Confirmation of the neuronal lineage of IM-PEN was performed with two different antibodies. Positive cytosolic staining of the pan neuronal marker PGP9.5 was present in cells differentiated for 7 days at $37^{\circ} \mathrm{C}$ and correlates with that described in the original paper after 15 passages of the cell line [12]. The microtubule protein $\beta$ III-tubulin (Tuj1) expression was also examined and appears as punctate staining in long strands and is present in a majority of the cells (Figure 1A-D). No staining was observed in the absence of primary antibodies.

\section{mRNA expression of ion channels in IM-PEN}

Peripherin, cRet, sodium, potassium, and chloride channels were expressed at both $33^{\circ} \mathrm{C}$ and $39^{\circ} \mathrm{C}$ in IM-FEN. At $39^{\circ} \mathrm{C}$ there was a significant increase in the expression of these markers and ion channels. To assess the quantitative changes, we performed real-time PCR on IM-FEN cells cultured at $33^{\circ} \mathrm{C}$ and $39^{\circ} \mathrm{C}$. As seen in Figure 2 we found a significant increase in cRet expression and peripherin at $39^{\circ} \mathrm{C}$.

There was about 26 fold increase in calcium-activated chloride channel regulator 1(Clca1), 18 fold of acid sensitive $\mathrm{K}^{+}$channel (TASK1), 12 fold of potassium intermediate/small conductance calcium-activated channel (Kcnn4), and voltage sensitive sodium channels $\left(\mathrm{NaV} \_1.3\right.$, and $\left.\mathrm{NaV} \_1.9\right)$ were 10 and 7 fold increase respectively at $39^{\circ} \mathrm{C}$ compared to $33^{\circ} \mathrm{C}$. These results indicate that under differentiating conditions there is an increase in channel expression and suggest that as the neurons mature they are transcribing the channels required for generation of electrophysiological responses indicative of enteric neurons.

\section{Passive membrane properties}

The immortalized enteric neurons (IM-EN) used for electrophysiological studies were identified morphologically as having neurites. In current clamp mode, using high $\mathrm{K}^{+}$internal pipette solution and normal external solution (solution 1 and internal solution A; Table 1 and 2 ), the fetal immortalized enteric neurons (IM-FEN) had a mean resting membrane potential of $-24.6 \pm 2.1 \mathrm{mV}(\mathrm{n}=6)$ and the post-natal immortalized enteric neurons (IM-PEN) cells had a mean resting membrane potential of $-29.8 \pm 0.9 \mathrm{mV}(\mathrm{n}=30)$. The mean capacitance of IMPEN was $37.2 \pm 1.9 \mathrm{pF}(\mathrm{n}=30)$ (Table 3$)$.

\section{Active properties}

The sin qua non of a neuron is the ability to fire sodium-dependent action potentials. A depolarized resting membrane potential will result in inactivated voltage gated sodium channels, thus to determine if IM-PEN cells are capable of eliciting action potentials, a hyperpolarizing current was provided to lower the resting potential to $-80 \mathrm{mV}$. Stepwise depolarization from a $\mathrm{Vh}=-80 \mathrm{mV}(\mathrm{n}=14)$ or from $\mathrm{Vh}=-60 \mathrm{mV}(\mathrm{n}=6)$, resulted in passive responses and failed to elicit action potentials (Figure 3) in IM-PEN. Fetal enteric neurons, 
IM-FEN, also failed to produce action potentials to depolarizing pulses at a $\mathrm{Vh}-60 \mathrm{mV}$ $(n=6)$ (data not shown). Since the immunohistochemistry and current clamp data remained consistent between IM-FEN and IM-PEN we pursued further analysis of the IM-PEN cell line with the hypothesis that the post-natal cells are more differentiated than the fetal cells as a result of age [16].

\section{Ion Channels}

Sodium Channels-IM-PEN express mRNA for at least two different voltage gated sodium channels $\left(\mathrm{Na}_{\mathrm{v}} 1.3\right.$ and $\left.\mathrm{Na}_{\mathrm{v}} 1.9\right)$. From a holding potential $(\mathrm{Vh})$ of $-80 \mathrm{mV}, 10 \mathrm{mV}$ step depolarizations were applied for $350 \mathrm{~ms}$. The internal pipette solution contained high $\mathrm{Cs}^{+}$to block $\mathrm{K}^{+}$currents and a normal external solution was used ( $1 \& \mathrm{C}$ in Tables, $1 \& 2$ ). Inward currents with an average current density of $-0.85 \pm 0.17 \mathrm{pA} \mathrm{pF}^{-1}(\mathrm{n}=11)$ were elicited with a peak at $-20 \mathrm{mV}$. Two methods were used to determine whether the inward current was sodium dependent; 1) replacement of the $\mathrm{Na}^{+}$cation with NMDG and 2) block with $2 \mu \mathrm{M}$ tetrodotoxin (TTX). Neither NMDG nor TTX significantly affected the inward currents. In the presence of NMDG at $-20 \mathrm{mV}$ an average current density of $-0.56 \pm 0.27 \mathrm{pA} \mathrm{pF}^{-1}(\mathrm{n}=3)$ (blue) was produced compared to $-0.73 \pm 0.19 \mathrm{pA} \mathrm{pF}^{-1}(\mathrm{n}=4)$ in $2 \mu \mathrm{M}$ TTX (red)(Figure 4). These data show that while $\mathrm{Na}^{+}$channels were transcribed, the resulting mRNA does not produce functional ion channels under cultured conditions.

Calcium Channels-IM-PEN cells were maintained at a holding potential of $-80 \mathrm{mv}$ and depolarized in $10 \mathrm{mV}$ steps in normal extracellular solution and internal solution (external \#1 and internal B in Tables $1 \& 2$ respectively). The current-voltage relationship in Figure 4C demonstrates inhibition when compared to the control $-0.85 \pm 0.17 \mathrm{pA} \mathrm{pF}^{-1}$ (closed circles) vs. nifedipine treatment $-0.42 \pm 0.12 \mathrm{pA} \mathrm{pF}^{-1}$ (open circles) at $-20 \mathrm{mV}(\mathrm{n}=4)$. The mean control current at $-20 \mathrm{mV}$ was $-0.86 \pm 0.5 \mathrm{pA} \mathrm{pF}^{-1}$ while that for $\omega$-conotoxin at $-20 \mathrm{mV}$ was $-0.97 \pm 0.61 \mathrm{pA} \mathrm{pF}^{-1}(\mathrm{n}=3)$ (data not shown).

Chloride Channels-With an internal solution containing $140 \mathrm{mM} \mathrm{Cs}^{+}$and external $146 \mathrm{mM} \mathrm{Cl}^{-}$(solution 1 and internal solution B), depolarization induced slightly outwardly rectifying currents (figure $5 \mathrm{~A}$ ). The currents were significantly reduced when perfused with a low chloride solution $(40 \mathrm{mM})$ (solution 4)(Figure 5B). Subtracted currents had a reversal potential of $-36.8 \mathrm{mV}(\mathrm{n}=6)$ (Figure 5C) which is close to the equilibrium potential for $\mathrm{Cl}^{-}$ of $-38 \mathrm{mV}$ for these solutions indicating a high intracellular $\mathrm{Cl}^{-}$concentration. Of note was the presence of slowly deactivating tail currents suggesting expression of a calciumactivated $\mathrm{Cl}^{-}$channel (Figure 5C). To test for this we examined the effect of niflumic acid (1 $\mathrm{uM})$. Figure $5 \mathrm{E}-\mathrm{G}$ show that both outward currents and the slow deactivating tail currents were significantly reduced by niflumic acid.

Hypoosmotically activated current-We next examined whether IM-PEN cells express volume-regulated anion currents (VRAC, $\mathrm{I}_{\mathrm{Cl} \text {,swell }}$ [17]. For these experiments, cells were held at either $-60 \mathrm{mV}$ or $+30 \mathrm{mV}$ to induce swelling-activated inward or outward currents, respectively. As seen in figure 6A,6C, perfusing a hypoosmotic solution (solution 6 to internal $\mathrm{C}$ in table 1) from $\mathrm{Vh}-60 \mathrm{mV}$ elicited an inward current that was blocked by the $\mathrm{I}_{\mathrm{Cl} \text {,swell }}$ blocker, DCPIB $(10 \mathrm{uM})$. The current-voltage relationship in hyposmotic solution showed a linear correlation with a reversal potential of $-21.3 \pm 4.5 \mathrm{mV}(\mathrm{n}=7)$ compared to the calculated reversal potential of $\mathrm{Cl}^{-}$of $-19.7 \mathrm{mV}$. As expected, when cells were held at +30 $\mathrm{mV}$, swelling activated currents were outward (9/11) and were blocked by gluconate indicating a $\mathrm{Cl}^{-}$sensitive channel.

TRPV1-RT-PCR data indicated likely transcription of TRPV1 expression which was confirmed using immunocytochemistry (Figure 7A). Interestingly, TRPV1 appeared largely 
to be cytosolic with no expression observed on the membrane. Whole cell voltage clamp experiments with solutions 1 and A (Table $1 \& 2$ respectively) confirmed that TRPV1 currents could not be activated by capsaicin $(10 \mu \mathrm{M})$. A continuous recording holding the cell at $-60 \mathrm{mV}$ for several minutes in the presence of $10 \mu \mathrm{M}$ capsaicin failed to yield a current (Figure $7 \mathrm{~B})(\mathrm{n}=4)$. At higher magnification $(60 \mathrm{X})$ the protein appeared to be localized to intracellular compartments.

\section{Smooth muscle and neuronal differentiation of IM-PEN}

Three different methods were used to determine if a signal derived from smooth muscle cells could aid in the electrophysiological differentiation of IM-PEN. The IM-PEN cells were grown in differentiation conditions with an equal parts mixture of smooth muscle media grown with smooth muscle cells for 5 days and the NBA differentiation media. The second method required the use of transwell plates in which the IM-PEN were separated from the smooth muscle layer by a $0.5 \mu \mathrm{m}$ filter. In the third method the IM-PEN cells were transfected with GFP and grown and differentiated directly on a layer of rabbit smooth muscle cells (Figure 8). All three of these techniques resulted in depolarized resting membrane potentials of $-13.4 \pm 1.6 \mathrm{mV}(\mathrm{n}=6),-18.8 \pm 2.4(\mathrm{n}=6)$, and $-13.0 \pm 2.8(\mathrm{n}=4)$ respectively.

The membrane area measured in $\mathrm{pF}$ was not significantly different between the three growth conditions $23.8 \pm 4.0(\mathrm{n}=6), 20.6 \pm 1.7(\mathrm{n}=6), 17.3 \pm 2.2(\mathrm{n}=4)$ respectively (table 3$)$. Representative current clamp and voltage clamp recordings from IM-PEN grown directly on rabbit smooth muscle (Figure 8A, 8B, 8C) clearly demonstrate that smooth muscle cells do not generate cells that fire action potentials from IM-PEN after 7 days in the differentiation protocol. The current-voltage relationship, Figure $8 \mathrm{D}$, also demonstrates that these growth conditions with smooth muscle did not alter the electrophysiological properties of IM-PEN.

\section{Transfection with L-type Calcium channel}

In order to establish whether ion channel protein expression and trafficking were globally inhibited in IM-PEN we transfected both the alpha and beta subunits of the human jejunal $\mathrm{Ca}^{2+}$ channel $\left(\mathrm{hCa}_{\mathrm{v}} 1.2 \mathrm{~b}\right)$, and EGFP. Transfected cells were identified by GFP and whole cell patch clamp measurements with $140 \mathrm{mM}$ internal $\mathrm{CsCl}$ and $10 \mathrm{mM} \mathrm{Ba}^{2+}$ external (solutions 3 and $\mathrm{C}$ from tables 1 and 2 respectively) solution were conducted.

The cells were depolarized from a holding potential of $-60 \mathrm{mV}$ and demonstrated a peak at $+20 \mathrm{mV}$ of $-8.7 \pm 0.72 \mathrm{pA} \mathrm{pF}^{-1}(\mathrm{n}=4)$, which was significantly different from cells transfected with EGFP alone $1.2 \pm 0.18 \mathrm{pA} \mathrm{pF}^{-1}(\mathrm{n}=6)$ (Figure 9).

\section{Discussion}

The mouse enteric neuron cell line developed from 2 day post-natal immortomice (IMPEN) has been previously shown to have several characteristics of enteric neurons. This includes expression of neuronal markers and enteric neurotransmitters and very little if any expression of glial cell or smooth muscle markers $[12,18]$. In agreement with this data we have shown that the majority of IM-PEN cells express the neuronal markers $\beta$ III-tubulin and PGP9.5 $[19,20]$. The major impetus for the present study was to discern the electrophysiological properties of these cells. Overall, our findings demonstrate that IMPEN cells express neuronal markers and mRNA for several ion channels, including $\mathrm{Na}^{+}, \mathrm{K}^{+}$, and $\mathrm{Cl}^{-}$however functional expression appears to be limited to L-type $\mathrm{Ca}^{2+}$ channels, a niflumic-acid sensitive and volume activated $\mathrm{Cl}^{-}$currents and $20 \%$ of cells contain a 4AP sensitive current (data not shown). Consistent with the lack of functional expression of voltage gated $\mathrm{Na}^{+}$channels, action potentials could not be generated in the IM-PEN cells. 
Interestingly, protein expression appears to be localized in intracellular compartments, at least for the TRPV1 channels, suggesting that at post-natal day 2, membrane trafficking of ion channels may be limiting functional expression. However, transfection of the alpha and beta subunits of $\mathrm{hCa}_{\mathrm{v}} 1.2 \mathrm{~b}$ into IM-PEN demonstrated that the machinery necessary for transcription, translation, protein folding and translocation are all present and functional in some form.

The majority of electrophysiological recordings from enteric neurons have been limited to the guinea-pig small intestine. The few recordings from mouse enteric neurons have largely utilized microelectrode impalements under current clamp conditions which provides information on the action potential configuration but does not allow for biophysical analysis of the underlying ion channels [5,21-23]. A study by Mao et al (2006) examined several ion channels in patch-clamp recordings from myenteric sensory neurons of the mouse small intestine [24]. To achieve this the authors exposed the myenteric plexus and recorded in-situ from the longitudinal muscle myenteric plexus preparation (LMMP) after exposing the ganglia by protease treatment and individual neurons by cleaning the surface with a fine hair. Liu et al (2002) examined cultured neurons from adult mice and demonstrated the expression of 5HT-induced inward currents [25]. These cells appeared to be a homogenous population and the distinction between $\mathrm{S}$ and $\mathrm{AH}$ neurons was not identified.

Several studies have identified voltage gated ion channels in guinea pig enteric neurons including Nav1.3, Nav1.7, Nav1.9, Kv1.5, intermediate conductance $\mathrm{Ca}^{2+}$ dependent $\mathrm{K}^{+}$ channel (IK), and N-type $\mathrm{Ca}^{2+}$ channels [26-33]. We found expression of NaV1.3 and $\mathrm{NaV1.9}$, as well as the IK channel, however voltage clamp whole cell measurements could not demonstrate a functional current resulting from these channels. As these cations are responsible for the action potential it correlates with our data that $\mathrm{Na}^{+}$channels are not functionally expressed whereas there is a low density of the L-type $\mathrm{Ca}^{2+}$ channel present in IM-PEN. In the presence of $\mathrm{Cs}^{+}$, expression of an outwardly rectifying channel which was reduced when $100 \mathrm{mM} \mathrm{Cl}^{-}$was removed from the external solution confirmed the expression of a chloride channel. Niflumic acid decreased the outward current as well as the slowly deactivating tail current suggesting the existence of a calcium activated chloride current $(\mathrm{CaCC})$. The CaCC's were observed in the presence of high internal EGTA and in the absence of voltage-gated calcium channels unlike those reported previously in smooth muscle cells [34]. Further studies will be required to establish their biophysical properties. A volume regulated anion channel (VRAC) also known as $\mathrm{I}_{\mathrm{Cl} \text {,swell }}$ was also functionally expressed in IM-PEN cells. When a cell is introduced into a hypoosmotic environment it swells as a result of the osmotic pressure exerted on it. In response, and to prevent rupture, the cell undergoes regulatory volume decrease (RVD) in which anions, cations, and organic osmolytes are expunged from the cell. For the most part these charged ions travel through transporters or ion channels [35]. The IM-PEN cell line did express a hypoosmotically activated current not previously recorded in myenteric neurons. The current was outward at a $\mathrm{Vh}$ of $+30 \mathrm{mV}$ and inward at a $\mathrm{Vh}$ of $-60 \mathrm{mV}$ and was inhibited by $10 \mathrm{uM}$ DCPIB which is consistent with $\mathrm{I}_{\mathrm{Cl} \text {,swell }}$ [36]. Notable however is the activation of this channel without internal ATP. Debate persists as to whether $\mathrm{I}_{\mathrm{Cl} \text {,swell }}$ requires ATP as shown by BryanSisneros et al. (2000) or does not as seen by Carpaneto et al. (1999) and Harvey et al (2009) [37-39]. Interestingly these examples of $\mathrm{I}_{\mathrm{Cl} \text {,swell }}$ which do not seem to require ATP were measured in neuronal cell lines and may represent a splice variant of $\mathrm{I}_{\mathrm{Cl} \text {,swell }}$. As this channel has not yet been cloned we were unable to measure mRNA levels [40]. It has been suggested that $\mathrm{I}_{\mathrm{Cl} \text {,swell }}$ may also respond to stretch [41]. A volume activated $\mathrm{Cl}^{-}$channel has not been previously demonstrated in adult myenteric neurons and therefore it is unclear as to whether $\mathrm{I}_{\mathrm{Cl} \text {,swell }}$ represents a unique component of post-natal neurons. 
The depolarized resting membrane potential of $-29.8 \pm 0.9 \mathrm{mV}(\mathrm{n}=30)$ in IM-PEN is near the reversal potential of chloride $(-38 \mathrm{mV})$ and signifies that IM-PEN have a relatively high internal chloride concentration. This may also preclude the normal conduction of ionic currents. Immature neurons of the rodent central nervous system have been found to have high intracellular chloride concentrations leading to outward GABA currents through postnatal development [42-44]. We were unable to measure currents to $100 \mu \mathrm{M}$ GABA in IM-PEN ( $\mathrm{n}=8$ ) under whole cell conditions (data not shown). We suspect that IM-PEN represents immature enteric neurons supported by the lack of action potentials and high internal chloride concentration. While the chemical coding for enteric neurons appears to be present in these cells, the electrophysiological properties resemble that of myofibroblasts. Interestingly, calcium channel overexpression was also not sufficient to induce action potentials, unlike the AH neurons. Important to note is that one week after GFP-transfected IM-FEN cells (E13) were transplanted into Piebald heterozygote and nNOS-/- mice an increase in neuronal function was seen (5). Recent studies by Raghavan et al. also illustrate that functional contact of these neurons with smooth muscle cells in vitro may induce electrical excitability [45]. This suggests that signaling events may induce maturation towards functional enteric neurons, although their differentiation to either sensory or motor requires further study. We examined the effect of smooth muscle cells on the electrophysiological properties of IM-PEN cells by either exposing to smooth muscle media or by plating onto smooth muscle directly. In neither case were the IM-PEN cells capable of evoked action potentials. Our data demonstrates that growth on smooth muscle alone is not enough to induce an active electrophysiological response in these cells.

Transfection of $\mathrm{hCa}_{\mathrm{v}} 1.2 \mathrm{~b}$ demonstrated that the cellular machinery of IM-PEN is functional. We showed that we could measure a voltage gated $\mathrm{Ca}^{2+}$ channel that is normally expressed in smooth muscle and do so in cells that have a neuronal lineage. This may demonstrate a useful property of IM-PEN in their current state to study the biophysics of ion channels if a neuronal cell line is desired. This result also lends credence to the hypothesis that a signal(s) might be necessary to fully differentiate the electrical properties of IM-PEN. If the signal is determined the molecular machinery may already be in place to transport the ion channels.

Understanding the signals involved in enteric neuron development stems largely from the investigation of Hirschsprung's disease in which the terminal bowel is aganglionic. Several genes have been identified which may be useful in converting the IM-PEN cell line into mature neurons such as RET, SOX10, and PHOX2B. Further studies will be required to establish which of these factors can induce enteric neuron maturation in culture for this cell line.

\section{Acknowledgments}

Funding Sources: This work was supported by NIH grants DK46367, DA024009 and T32DA007027 and NIHRO1 (DK080684, SS), VA-MERIT award (SS)

\section{Abbreviations}

IM-FEN Immortalized fetal enteric neurons

IM-PEN Immortalized post-natal enteric neurons

DCPIB 4-[(2-Butyl-6,7-dichloro-2-cyclopentyl-2,3-dihydro-1-oxo-1H-inden-5yl)oxy]butanoic acid 


\section{References}

1. Brookes SJ, Ewart WR, Wingate DL. Intracellular recordings from myenteric neurones in the human colon. J Physiol. 1987; 390:305-18. [PubMed: 2895177]

2. Costa M, Brookes SJ, Hennig GW. Anatomy and physiology of the enteric nervous system. Gut. 2000; 47(Suppl 4):iv15, 9. discussion iv26. [PubMed: 11076898]

3. Hirst GD, Holman ME, Spence I. Two types of neurones in the myenteric plexus of duodenum in the guinea-pig. J Physiol. 1974; 236:303-26. [PubMed: 16992436]

4. Mongardi Fantaguzzi C, Thacker M, Chiocchetti R, Furness JB. Identification of neuron types in the submucosal ganglia of the mouse ileum. Cell Tissue Res. 2009; 336:179-8. [PubMed: 19326148]

5. Nurgali K, Stebbing MJ, Furness JB. Correlation of electrophysiological and morphological characteristics of enteric neurons in the mouse colon. J Comp Neurol. 2004; 468:112-24. [PubMed: 14648694]

6. Furness JB, Jones C, Nurgali K, Clerc N. Intrinsic primary afferent neurons and nerve circuits within the intestine. Prog Neurobiol. 2004; 72:143-64. [PubMed: 15063530]

7. Hirst GD, Johnson SM, van Helden DF. The slow calcium-dependent potassium current in a myenteric neurone of the guinea-pig ileum. J Physiol. 1985; 361:315-37. [PubMed: 2580979]

8. Hodgkiss JP, Lees GM. Morphological studies of electrophysiologically-identified myenteric plexus neurons of the guinea-pig ileum. Neuroscience. 1983; 8:593-608. [PubMed: 6856086]

9. Lomax AE, Bertrand PP, Furness JB. Electrophysiological characteristics distinguish three classes of neuron in submucosal ganglia of the guinea-pig distal colon. Neuroscience. 2001; 103:245-5. [PubMed: 11311805]

10. Rugiero F, Gola M, Kunze WA, et al. Analysis of whole-cell currents by patch clamp of guinea-pig myenteric neurones in intact ganglia. J Physiol. 2002; 538:447-63. [PubMed: 11790812]

11. Osorio N, Delmas P. Patch clamp recording from enteric neurons in situ. Nat Protoc. 2010; 6:1527. [PubMed: 21212776]

12. Anitha M, Joseph I, Ding X, et al. Characterization of fetal and postnatal enteric neuronal cell lines with improvement in intestinal neural function. Gastroenterology. 2008; 134:1424-35. [PubMed: 18471518]

13. Noble M, Groves AK, Ataliotis P, et al. The H-2KbtsA58 transgenic mouse: a new tool for the rapid generation of novel cell lines. Transgenic Res. 1995; 4:215-2. [PubMed: 7655511]

14. Teng B, Murthy KS, Kuemmerle JF, et al. Expression of endothelial nitric oxide synthase in human and rabbit gastrointestinal smooth muscle cells. Am J Physiol. 1998; 275:G342-51. [PubMed: 9688662]

15. Anitha M, Chandrasekharan B, Salgado JR, et al. Glial-derived neurotrophic factor modulates enteric neuronal survival and proliferation through neuropeptide Y. Gastroenterology. 2006; 131:1164-78. [PubMed: 17030186]

16. Foong JP, Nguyen TV, Furness JB, et al. Myenteric neurons of the mouse small intestine undergo significant electrophysiological and morphological changes during postnatal development. J Physiol. 2012; 590:2375-90. [PubMed: 22371477]

17. Ackerman MJ, Wickman KD, Clapham DE. Hypotonicity activates a native chloride current in Xenopus oocytes. J Gen Physiol. 1994; 103:153-79. [PubMed: 8189203]

18. Anitha M, Shahnavaz N, Qayed E, et al. BMP2 promotes differentiation of nitrergic and catecholaminergic enteric neurons through a Smad1-dependent pathway. Am J Physiol Gastrointest Liver Physiol. 2010; 298:G375-83. [PubMed: 20007850]

19. Caccamo D, Katsetos CD, Herman MM, et al. Neuron-associated beta-tubulin as a marker for primitive neuroepithelium. Lab Invest. 1989; 60:390-8. [PubMed: 2467076]

20. Young HM, Bergner AJ, Muller T. Acquisition of neuronal and glial markers by neural crestderived cells in the mouse intestine. J Comp Neurol. 2003; 456:1-11. [PubMed: 12508309]

21. Bian X, Ren J, DeVries M, et al. Peristalsis is impaired in the small intestine of mice lacking the P2X3 subunit. J Physiol. 2003; 551:309-22. [PubMed: 12813150]

22. Furukawa K, Taylor GS, Bywater RA. An intracellular study of myenteric neurons in the mouse colon. J Neurophysiol. 1986; 55:1395-406. [PubMed: 3016211] 
23. Ren J, Bian X, DeVries M, et al. P2X2 subunits contribute to fast synaptic excitation in myenteric neurons of the mouse small intestine. J Physiol. 2003; 552:809-21. [PubMed: 12937291]

24. Mao Y, Wang B, Kunze W. Characterization of myenteric sensory neurons in the mouse small intestine. Journal of neurophysiology. 2006; 96:998-1010. [PubMed: 16899648]

25. Liu MT, Rayport S, Jiang Y, et al. Expression and function of 5-HT3 receptors in the enteric neurons of mice lacking the serotonin transporter. American journal of physiology. 2002; 283:G1398-411. [PubMed: 12388212]

26. Copel C, Osorio N, Crest M, et al. Activation of neurokinin 3 receptor increases $\mathrm{Na}(\mathrm{v}) 1.9$ current in enteric neurons. J Physiol. 2009; 587:1461-79. [PubMed: 19204045]

27. Neylon CB, Nurgali K, Hunne B, et al. Intermediate-conductance calcium-activated potassium channels in enteric neurones of the mouse: pharmacological, molecular and immunochemical evidence for their role in mediating the slow afterhyperpolarization. J Neurochem. 2004; 90:141422. [PubMed: 15341525]

28. Rugiero F, Mistry M, Sage D, et al. Selective expression of a persistent tetrodotoxin-resistant Na+ current and NaV1. 9 subunit in myenteric sensory neurons. J Neurosci. 2003; 23:2715-25. [PubMed: 12684457]

29. Sage D, Salin P, Alcaraz G, et al. $\mathrm{Na}(\mathrm{v}) 1.7$ and $\mathrm{Na}(\mathrm{v}) 1.3$ are the only tetrodotoxin-sensitive sodium channels expressed by the adult guinea pig enteric nervous system. J Comp Neurol. 2007; 504:363-78. [PubMed: 17663442]

30. Starodub AM, Wood JD. A-type potassium current in myenteric neurons from guinea-pig small intestine. Neuroscience. 2000; 99:389-96. [PubMed: 10938445]

31. Vianna-Jorge R, Oliveira CF, Garcia ML, et al. Correolide, a nor-triterpenoid blocker of Shakertype Kv1 channels elicits twitches in guinea-pig ileum by stimulating the enteric nervous system and enhancing neurotransmitter release. Br J Pharmacol. 2000; 131:772-8. [PubMed: 11030727]

32. Zholos AV, Baidan LV, Starodub AM, Wood JD. Potassium channels of myenteric neurons in guinea-pig small intestine. Neuroscience. 1999; 89:603-18. [PubMed: 10077339]

33. Bartoo AC, Sprunger LK, Schneider DA. Expression and distribution of TTX-sensitive sodium channel alpha subunits in the enteric nervous system. J Comp Neurol. 2005; 486:117-31. [PubMed: 15844213]

34. Akbarali HI, Giles WR. Ca2+ and $\mathrm{Ca}(2+)$-activated $\mathrm{Cl}$ - currents in rabbit oesophageal smooth muscle. The Journal of physiology. 1993; 460:117-33. [PubMed: 7683715]

35. Hoffmann EK, Lambert IH, Pedersen SF. Physiology of cell volume regulation in vertebrates. Physiol Rev. 2009; 89:193-277. [PubMed: 19126758]

36. Abdullaev IF, Rudkouskaya A, Schools GP, et al. Pharmacological comparison of swellingactivated excitatory amino acid release and $\mathrm{Cl}-$ currents in cultured rat astrocytes. J Physiol. 2006; 572:677-89. [PubMed: 16527858]

37. Bryan-Sisneros A, Sabanov V, Thoroed SM, Doroshenko P. Dual role of ATP in supporting volume-regulated chloride channels in mouse fibroblasts. Biochim Biophys Acta. 2000; 1468:6372. [PubMed: 11018652]

38. Carpaneto A, Accardi A, Pisciotta M, Gambale F. Chloride channels activated by hypotonicity in N2A neuroblastoma cell line. Exp Brain Res. 1999; 124:193-9. [PubMed: 9928842]

39. Harvey VL, Saul MW, Garner C, McDonald RL. A role for the volume regulated anion channel in volume regulation in the murine CNS cell line, CAD. Acta Physiol(Oxf). 2010; 198:159-68. [PubMed: 19811460]

40. Okada Y, Sato K, Numata T. Pathophysiology and puzzles of the volume-sensitive outwardly rectifying anion channel. J Physiol. 2009

41. Browe DM, Baumgarten CM. Stretch of beta 1 integrin activates an outwardly rectifying chloride current via FAK and Src in rabbit ventricular myocytes. J Gen Physiol. 2003; 122:689-702. [PubMed: 14610020]

42. Ben-Ari Y, Gaiarsa JL, Tyzio R, Khazipov R. GABA: a pioneer transmitter that excites immature neurons and generates primitive oscillations. Physiol Rev. 2007; 87:1215-84. [PubMed: 17928584]

43. Wang DD, Kriegstein AR. Defining the role of GABA in cortical development. J Physiol. 2009; 587:1873-9. [PubMed: 19153158] 
44. Li H, Tornberg J, Kaila K, et al. Patterns of cation-chloride cotransporter expression during embryonic rodent CNS development. Eur J Neurosci. 2002; 16:2358-70. [PubMed: 12492431]

45. Raghavan S, Gilmont RR, Miyasaka EA, et al. Successful Implantation of Bioengineered, Intrinsically Innervated, Human Internal Anal Sphincter. Gastroenterology. 2011 

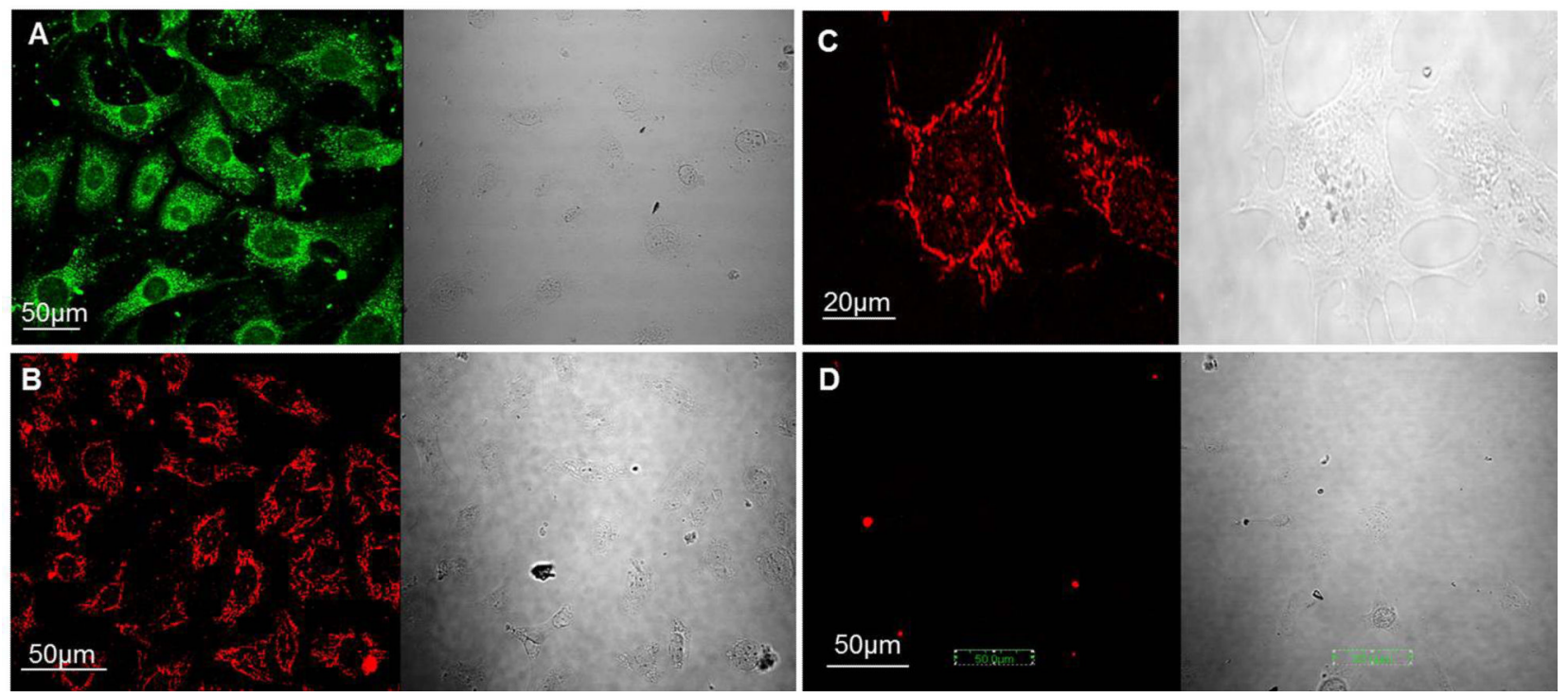

Figure 1. IM-PEN exhibits positive immunoreactivity for the neuronal marker PGP 9.5 and $\beta$ III tubulin (Tuj1)

A) PGP9.5 immunoreactivity (green) 20X B) $\beta$ III-tubulin immunoreactivity (red) 20X C) higher magnification of $\beta$ III-tubulin (red) $60 \mathrm{X} \mathrm{D}$ ) control in the absence of primary antibody 20X. Each is shown with its corresponding brightfield image. 
A

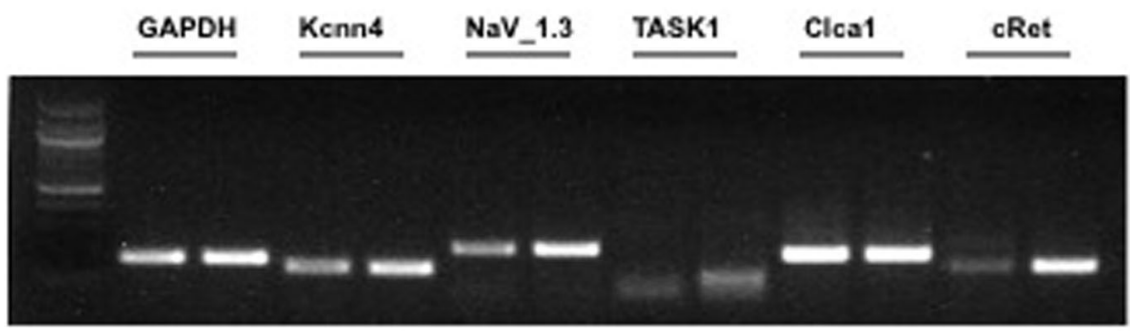

B

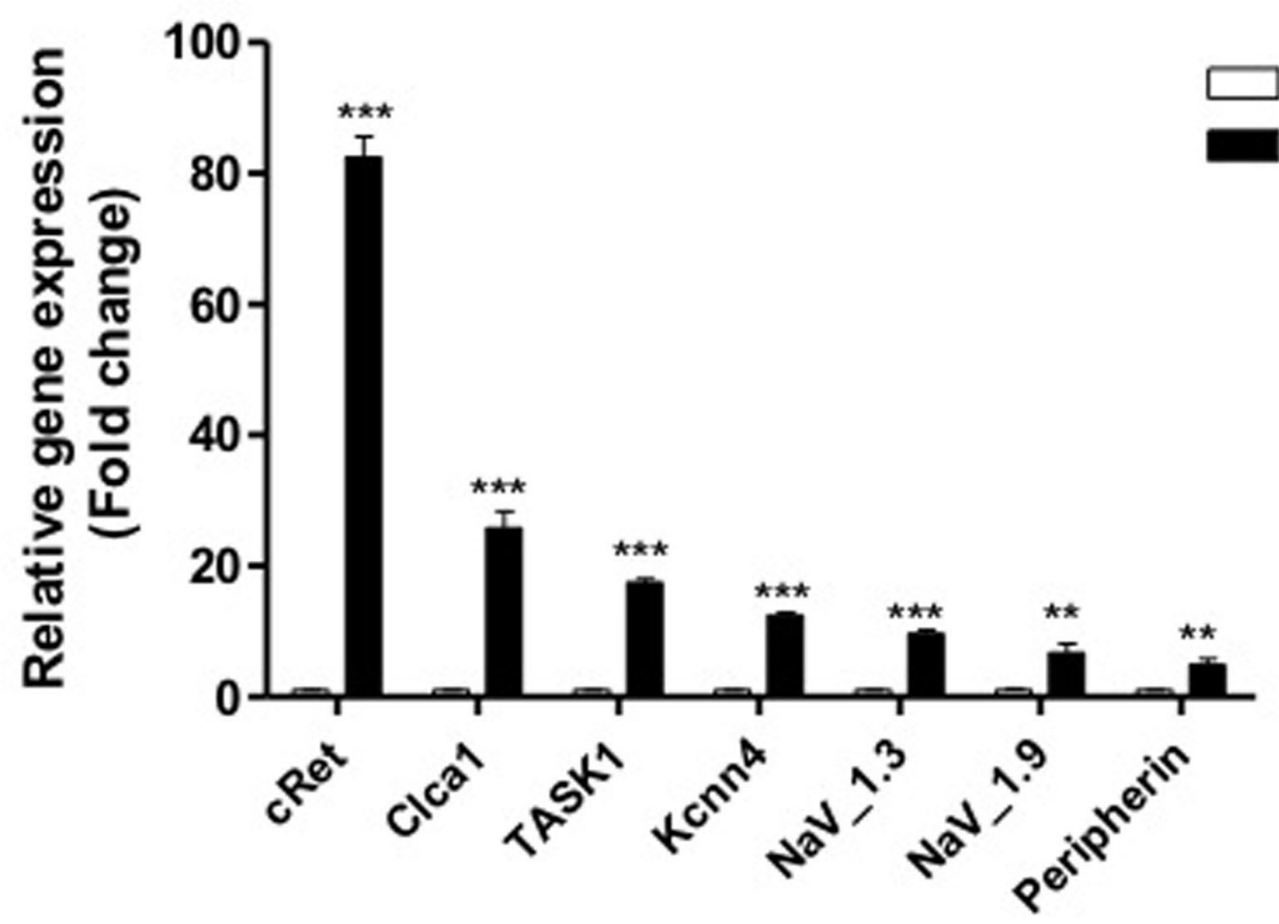

Figure 2. Expression of neuronal markers and channels in IM-FEN cultured at $39^{\circ} \mathrm{C}$ ( 3 days) compared to cells cultured at $33^{\circ} \mathrm{C}$

(A) RNA was isolated from IM-FEN cultured at $33^{\circ} \mathrm{C}$ or $39^{\circ} \mathrm{C}$ ( 3 days) and amplified for cRet, Kcnn4, NaV_1.3, TASK1, Clca1, and GAPDH (loading control), $\mathrm{n}=3$. The two lanes/ gene correspond to RNA isolated from cells grown at $33^{\circ} \mathrm{C}$ and $39^{\circ} \mathrm{C}$. (B) Histogram for IM-FEN mRNA assessed by Real Time PCR showing the relative level of expression of various channels and neuronal markers, Peripherin and Ret after normalization to GAPDH expression. Results are mean \pm S.E., $\mathrm{n}=3$. $* * P<0.01, * * * P<0.001$. 


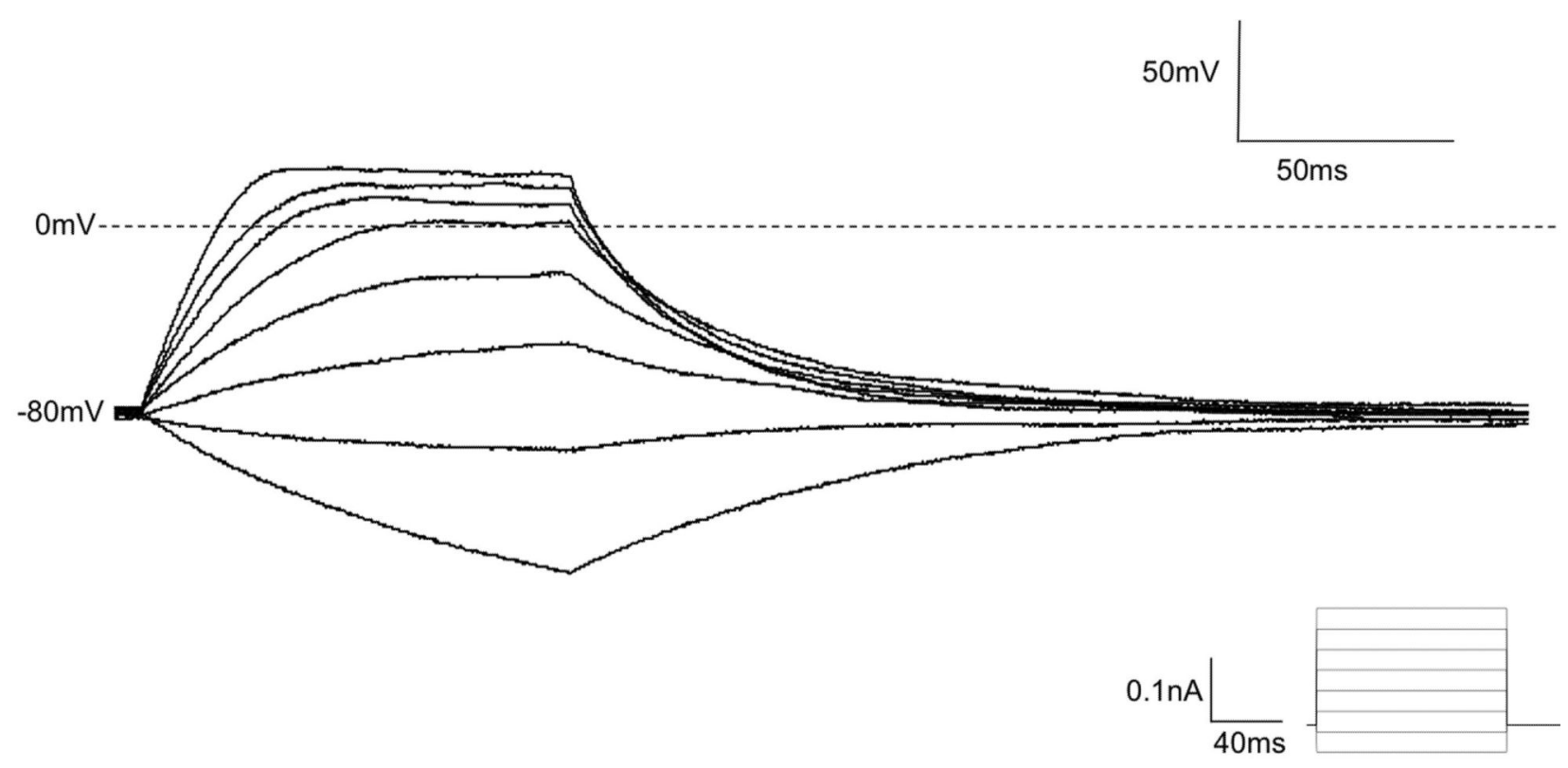

Figure 3. Whole cell current clamp recording of IM-PEN cell

A) Depolarizing current pulses elicited passive responses and large electrotonic potential with hyperpolarizing pulses. A hyperpolarizing current was applied to maintain a holding potential of $-80 \mathrm{mV}$. 
A

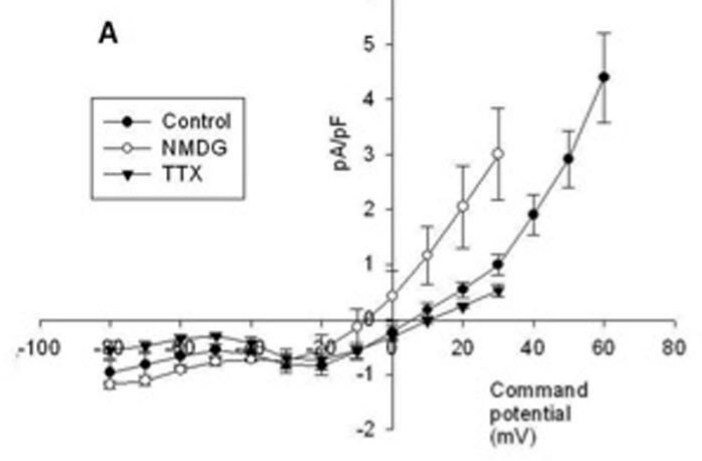

C

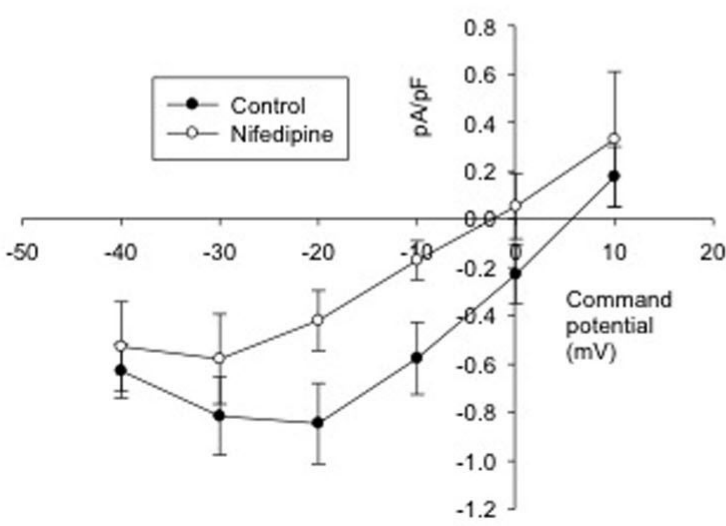

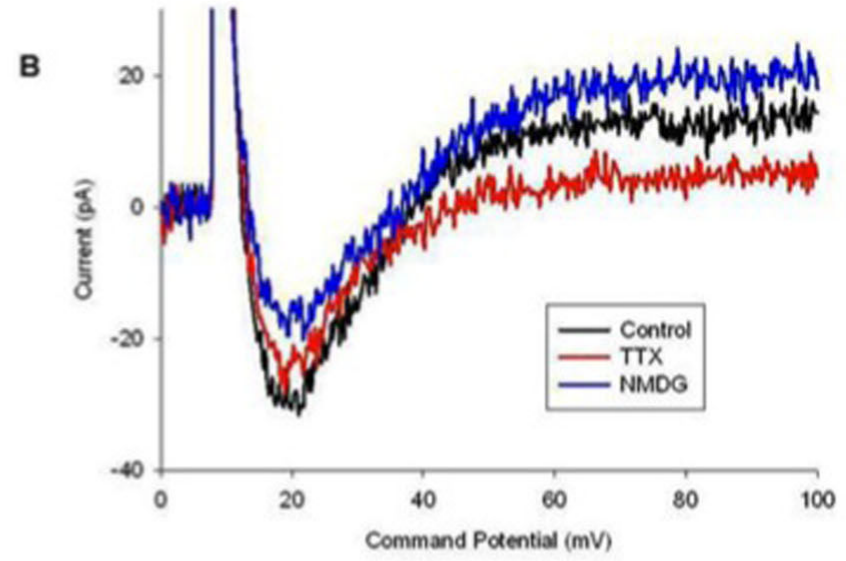

D

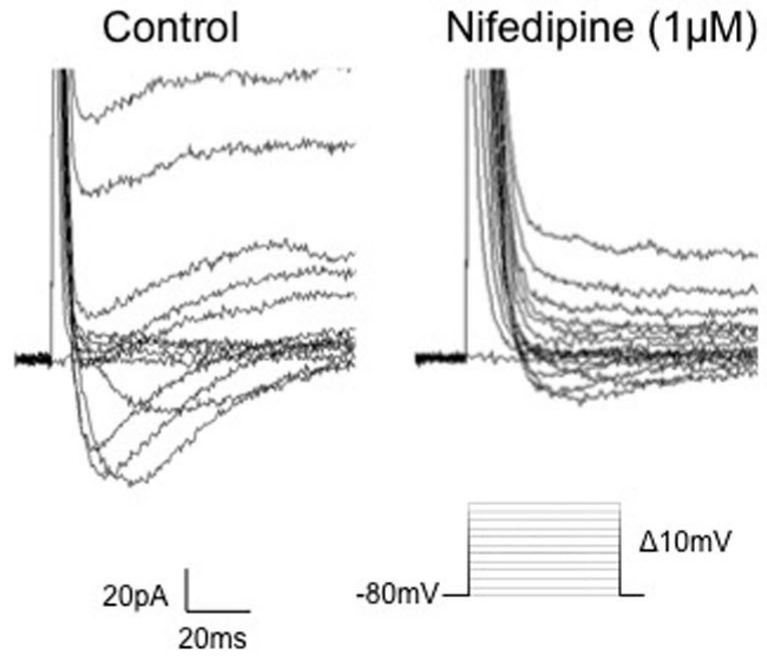

Figure 4. Voltage gated $\mathrm{Na}^{+}$and $\mathrm{Ca}^{2+}$ currents

A) A current-voltage relationship of peak currents in control (closed circles, $n=11$ ), following replacement of $\mathrm{Na}^{+}$with NMDG (open circles) $(\mathrm{n}=3)$ and in the presence of TTX $(2 \mu \mathrm{M})(\mathrm{n}=4)$ (closed triangles). B) Raw tracings of inward currents at the peak potential of $-20 \mathrm{mV}$ from same cell, treated with NMDG (blue) or TTX (red). C) Current-voltage relationship, control (closed circles) and inhibition with $1 \mu \mathrm{M}$ nifedipine (open circles) $(\mathrm{n}=4)$. D) Raw trace shows inhibition of the inward current with $1 \mu \mathrm{M}$ nifedipine. 

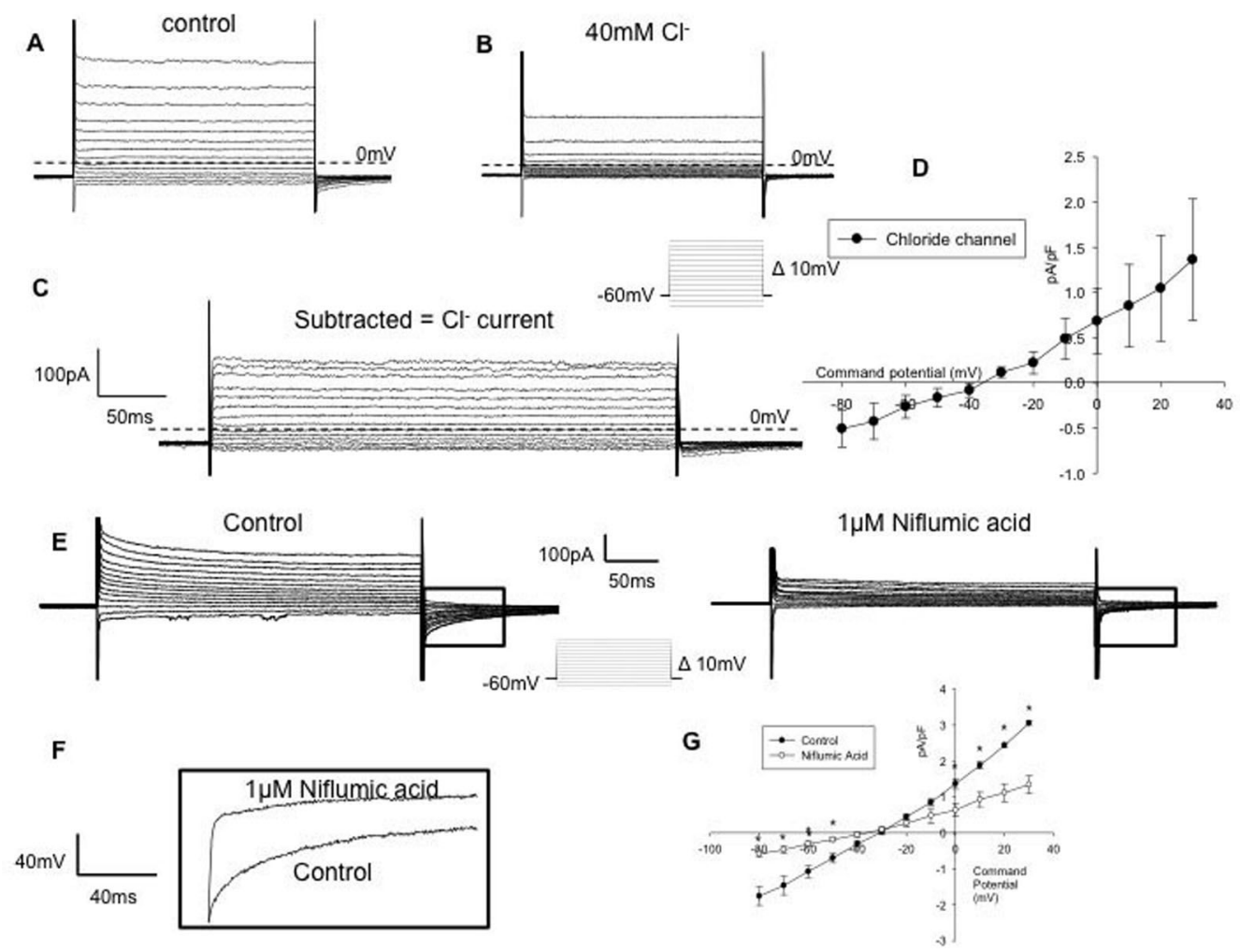

Figure 5. IM-PEN cells contain $\mathrm{Cl}^{-}$currents

A) Voltage clamp experiment in the whole cell configuration with $\mathrm{K}^{+}$channels blocked by $140 \mathrm{mM} \mathrm{CsCl}$ in the internal solution and $144 \mathrm{mM} \mathrm{Cl}^{-}$in the external solution $\mathrm{E}_{\mathrm{Cl}}=-38 \mathrm{mV}$. B) Same cell recorded with $40 \mathrm{mM} \mathrm{Cl}^{-}$in the external solution produces smaller currents. C) $\mathrm{Cl}^{-}$sensitive current obtained by subtraction. D) IV curve of chloride currents $(\mathrm{n}=6)$. E)

Niflumic acid ( $1 \mu \mathrm{M}$ NA) inhibited both the outward currents and tail currents. F) Expanded traces of tail currents from test pulse of $+30 \mathrm{mV}$ in the absence and presence of $1 \mu \mathrm{M} \mathrm{NA}$. G) IV relationship of amplitude of end of pulse current in the absence and presence of $1 \mu \mathrm{M}$ NA. 
A

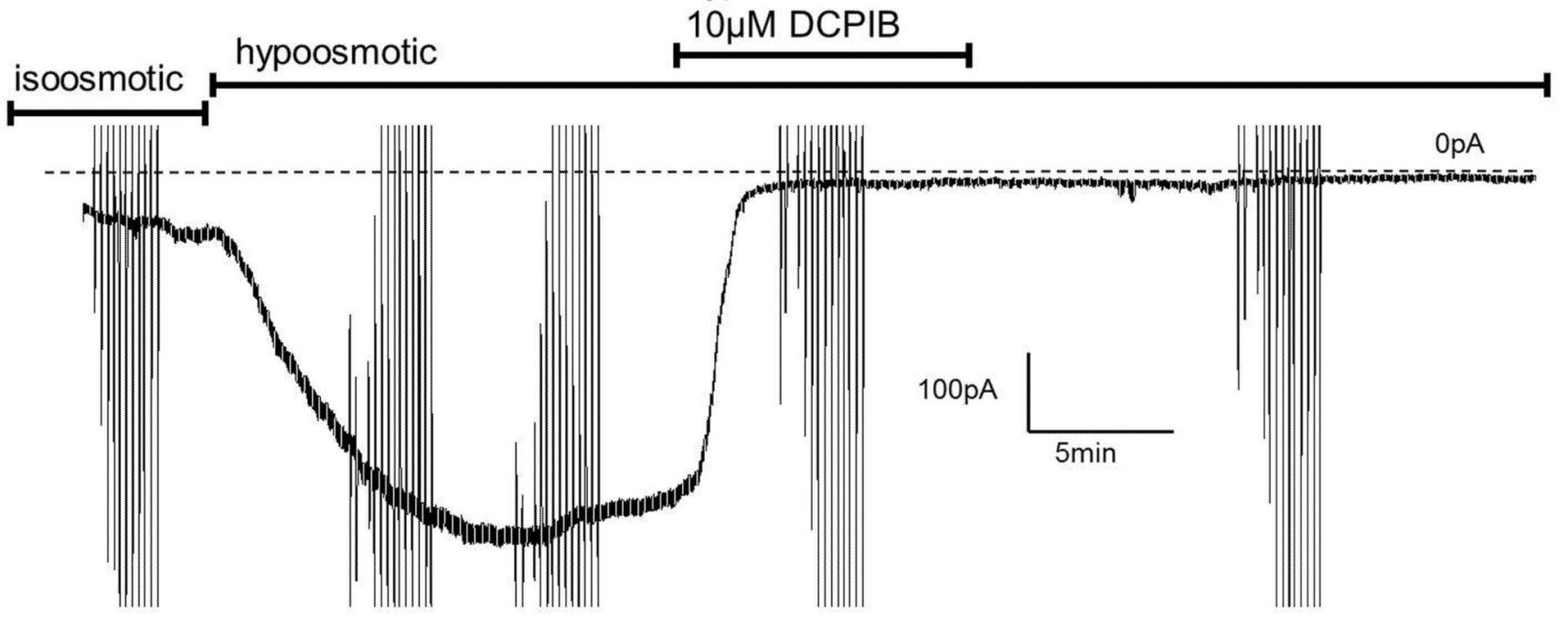

B

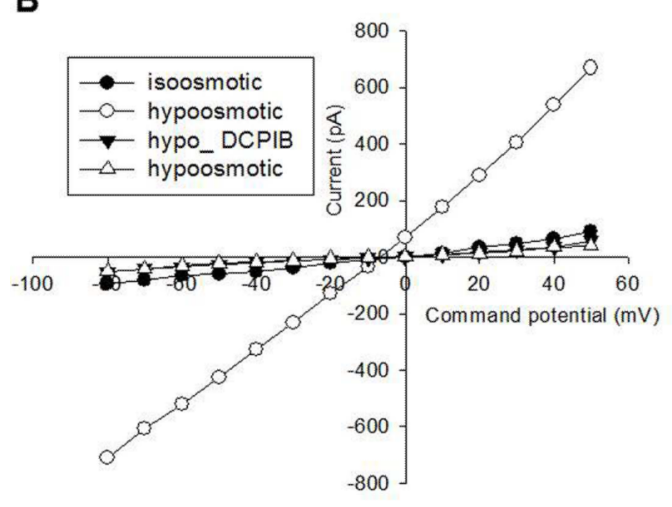

C
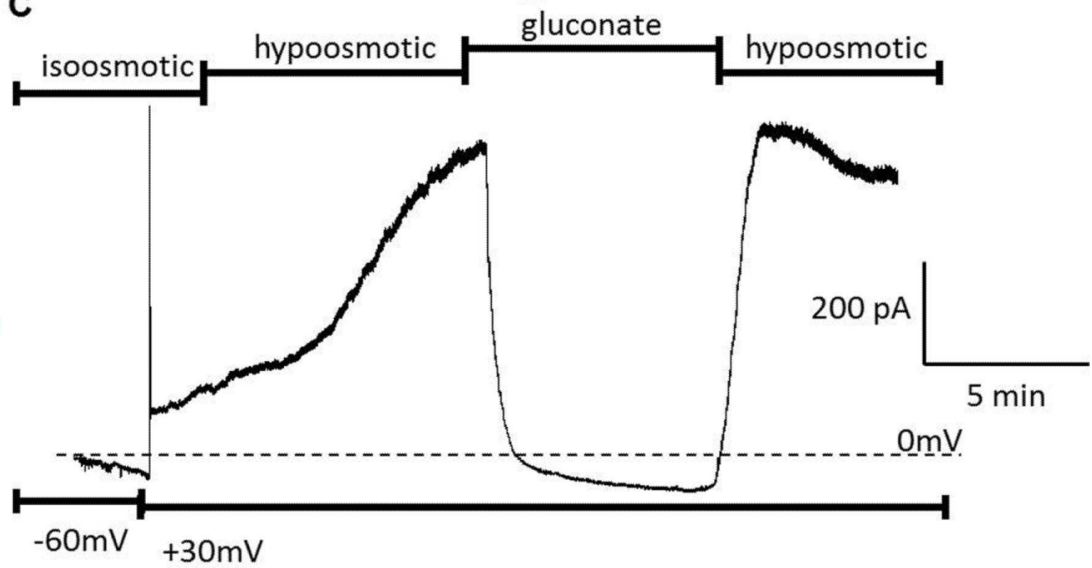

Figure 6. A hypoosmotically activated chloride current

A) Whole cell voltage clamp recording at $\mathrm{Vh}=-60 \mathrm{mV}$ initiated an inward current upon the perfusion of hypoosmotic solution (230mOsm). This current was inhibited and remained inhibited after treatment with $10 \mu \mathrm{M}$ DCPIB. B) IV- relationship showing swelling activated current and inhibition by DCPIB. C) Whole cell recording of IM-PEN with Vh $=+30 \mathrm{mV}$. Addition of hypoosmotic solution initiated an outward current which was inhibited when $\mathrm{Cl}^{-}$was replaced in the external solution with gluconate. The current returned when $\mathrm{Cl}^{-}$was returned to the external solution. 
A

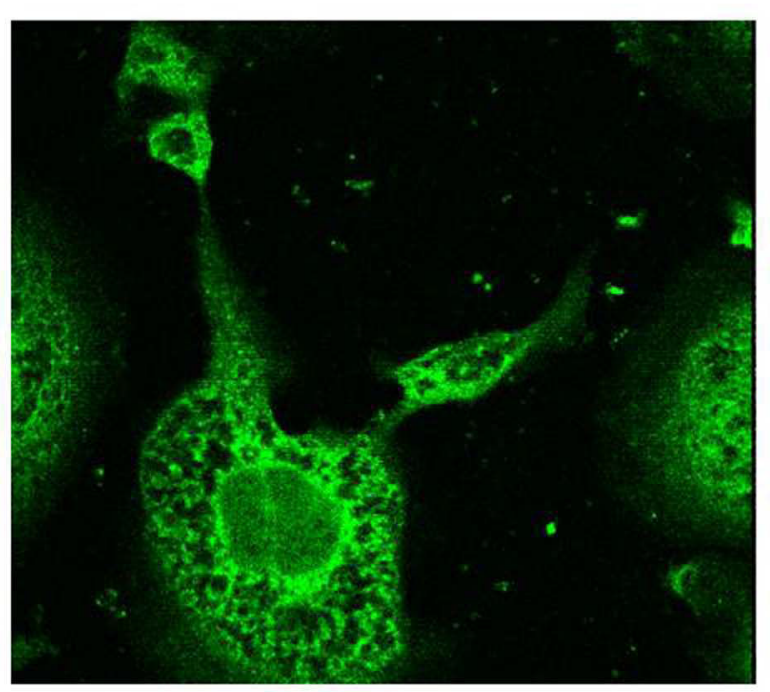

\section{Capsaicin $(10 \mu \mathrm{M})$}

B

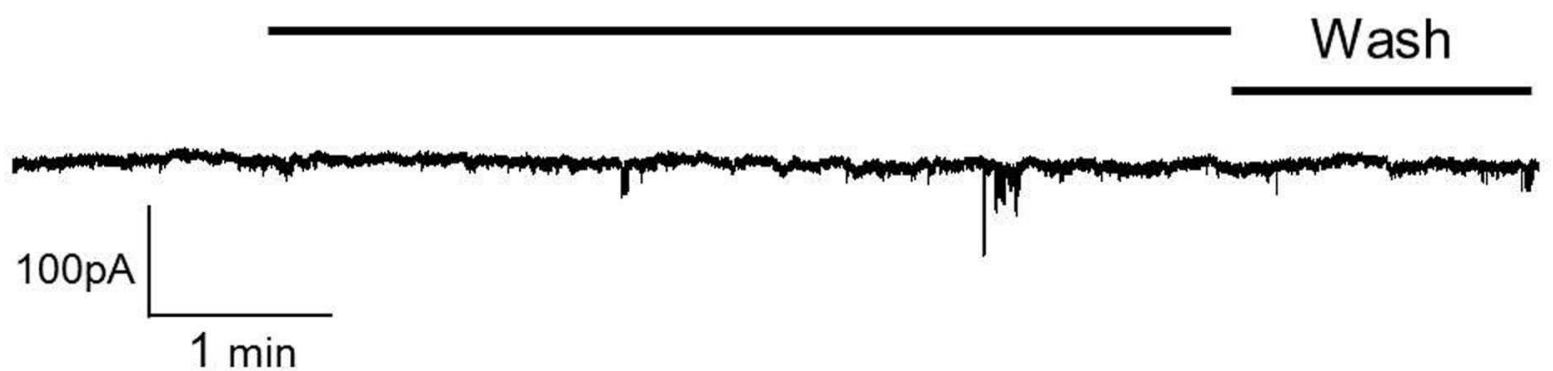

Figure 7. TRPV1 channel

A) TRPV1 positive immuno-reactivity of IM-PEN after 7 days at $37^{\circ} \mathrm{C}(20 \mathrm{X})$. Side panel shows immuno-reactivity in intracellular vesicles at higher magnification (60X). B) Whole cell voltage clamp recording from IM-PEN cell held at $-60 \mathrm{mV}$ and treated with $10 \mu \mathrm{M}$ capsaicin. No currents were elicited in the presence of capsaicin. 

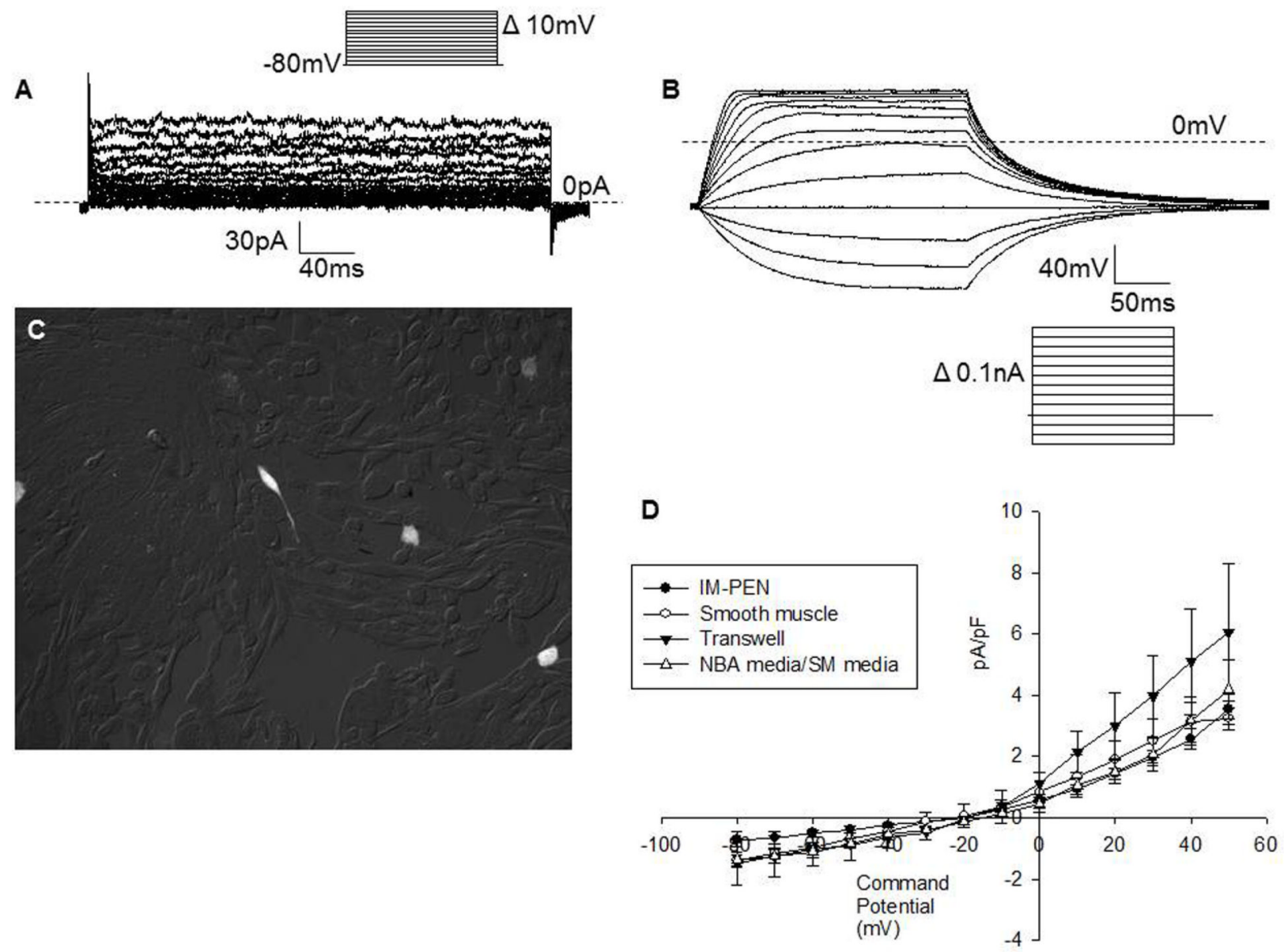

Figure 8. IM-PEN grown on rabbit smooth muscle

A) Representative voltage clamp recording from GFP transfected IM-PEN grown on rabbit smooth muscle. B) Current clamp recording from the same cell shows no action potentials to depolarizing pulses with a $\mathrm{Vh}-80 \mathrm{mV}$. C) Image of GFP transfected IM-PEN (white) plated on cultured rabbit smooth muscle cells. D) Current voltage relationship of IM-PEN grown in 3 different conditions with smooth muscle cells. 

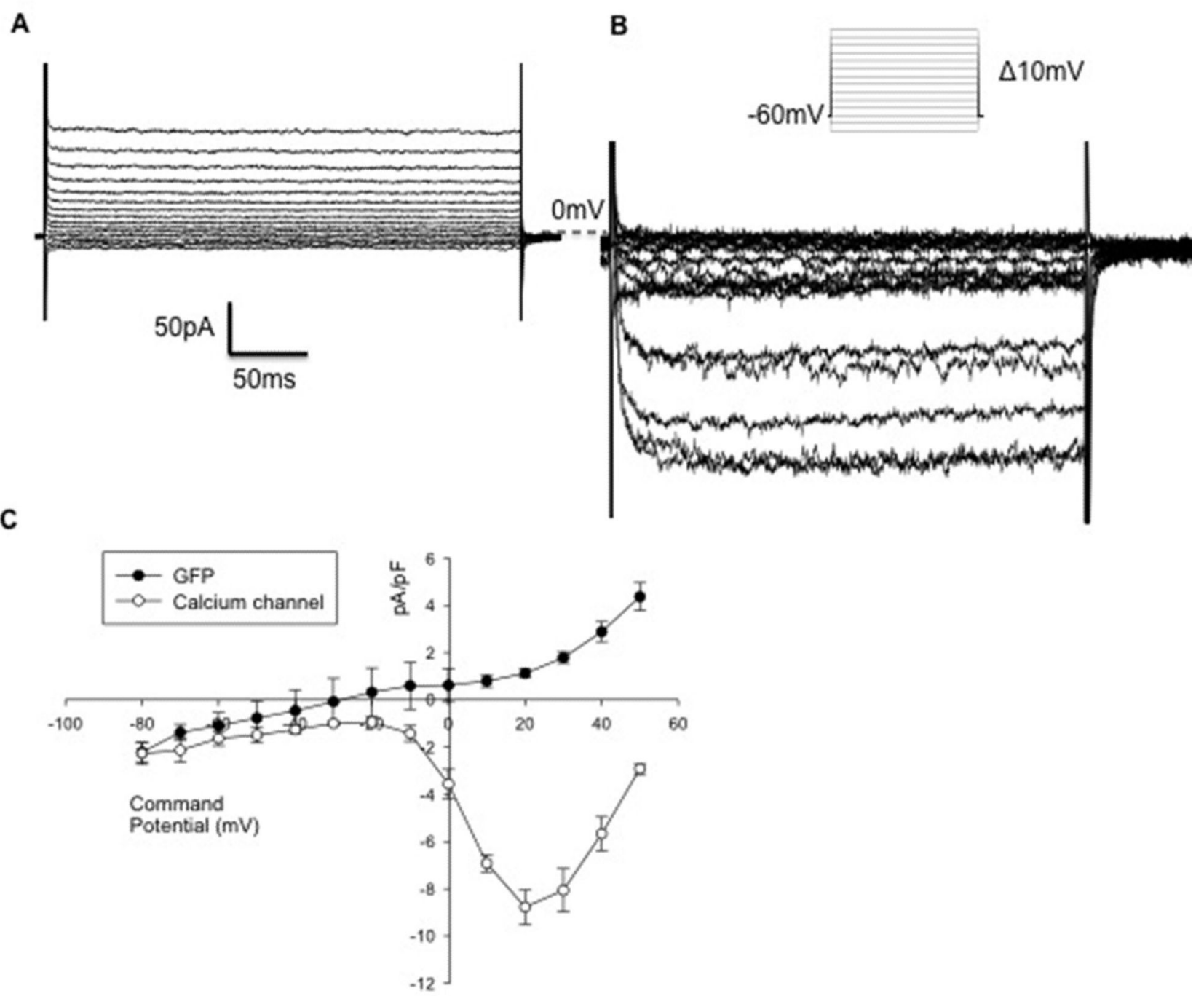

Figure 9. Transfection of IM-PEN with the voltage gated $\mathrm{Ca}^{2+}$ channel $\left(\mathrm{Ca}_{\mathrm{v}} 1.2 \mathrm{~b}\right)$ A) Raw trace of whole cell voltage clamp recording with internal $\mathrm{CsCl}(140 \mathrm{mM})$ in the presence of $10 \mathrm{mM}$ external $\mathrm{Ba}^{2+}$ of a GFP transfected cell. B) Raw trace of GFP and $\mathrm{Ca}_{\mathrm{v}} 1.2 \mathrm{~b}$ transfected cell displayed a peak inward current of $-8.7 \pm 0.72 \mathrm{pA} \mathrm{pF}^{-1}$ at $20 \mathrm{mV}$ $(\mathrm{Vh}=-60 \mathrm{mV}) . \mathrm{C})$ Current-voltage relationship of GFP transfected cells vs. those transfected with GFP and $\mathrm{Ca}_{\mathrm{v}} 1.2 \mathrm{~b}$. 


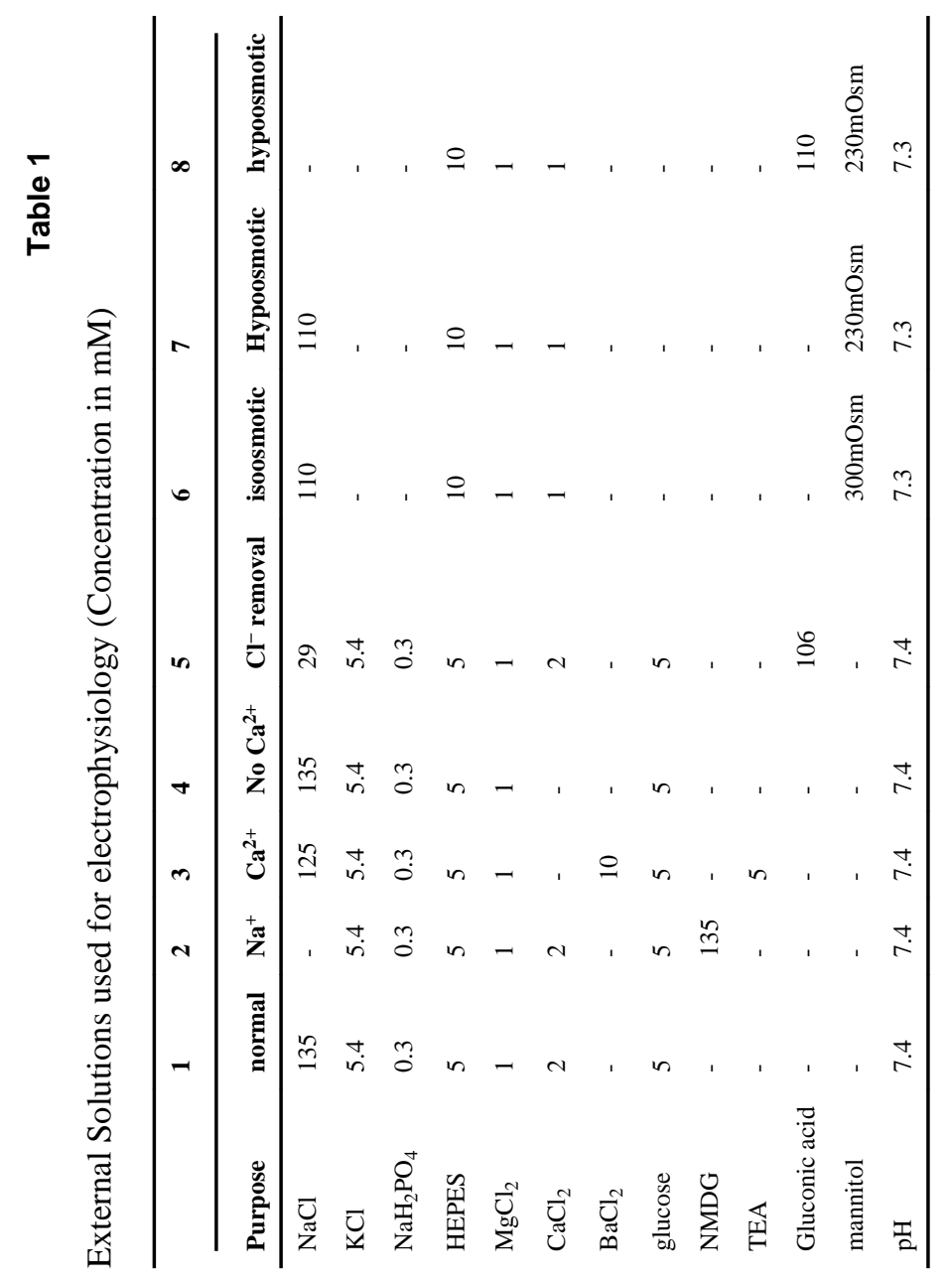

Dig Dis Sci. Author manuscript; available in PMC 2014 June 01. 
Table 2

Internal solutions for electrophysiology (Concentration in mM)

\begin{tabular}{lllll}
\hline & A & B & C & D \\
\hline Purpose & normal & low EGTA & Ca $^{2+}$ & Isotonic Cs \\
\hline K-aspartate & 100 & 100 & - & - \\
$\mathrm{KCl}$ & 30 & 30 & - & - \\
$\mathrm{ATP}-\mathrm{Mg}$ & 4.5 & 4.5 & 4.5 & - \\
$\mathrm{MgCl}_{2}$ & 1 & 1 & 2 & 1 \\
$\mathrm{HEPES}$ & 10 & 10 & 10 & 10 \\
$\mathrm{EGTA}$ & 6 & 0.1 & 10 & - \\
$\mathrm{Cs}-\mathrm{aspartate}$ & - & - & 100 & - \\
$\mathrm{CsCl}$ & - & - & 30 & 50 \\
$\mathrm{NaCl}$ & - & - & - & - \\
$\mathrm{Mannitol}$ & - & - & - & $290 \mathrm{mOsm}$ \\
$\mathrm{pH}$ & 7.2 & 7.2 & 7.2 & 7.3 \\
\hline
\end{tabular}

Dig Dis Sci. Author manuscript; available in PMC 2014 June 01. 
